\title{
EFEK PROTEKTIF VITAMIN E DAN SELENIUM TERHADAP KADAR KOLESTEROL DARAH PADA PENDERITA PENYAKIT JANTUNG
}

\author{
Widia Pebri Diana, Tetes Wahyu, Emy Yuliantini, \\ Politeknik Kesehatan Kementerian Kesehatan Bengkulu, Jurusan Gizi, \\ Jalan Indragiri Nomor 03 Padang Harapan Kota Bengkulu \\ ewhiedz_dc28@yahoo.co.id
}

\begin{abstract}
Cardiovascular disease (CVD) is a disease which disturbing the cardiovascular system. CVD is a disesase that can be prevented; $50 \%$ of death can be prevented by changing the food habit. The aim is to know relationship of vitamine $\mathrm{E}$ and celenium with total cholesterol concentration in CVD patient in RSUD dr. M. Yunus Bengkulu 2013. Research design is cross sectional. Data are analysed by univariat and bivariat analysis, correlation test. The sample are 35 people. The results of this research show that meaningfull relationship between vitamine $\mathrm{E}$ intake and total cholesterol consentration $(p=0.02)$, and celenium intake with total cholesterol consentration $(p=0.037)$ on CVD patient.
\end{abstract}

Keywords : Vitamin E Intake, Selenium, Total Cholesterol Concentration, CVD Patient

\begin{abstract}
Abstrak : Penyakit jantung adalah penyakit yang mengganggu sistem pembuluh darah. Penyakit Jantung dan Pembuluh Darah (PJPD) ini adalah suatu penyakit yang dapat dicegah, 50\% kematian dini dapat dicegah dengan upaya-upaya pencegahan yang mengenai perubahan gaya hidup yaitu pola makan. Tujuan penelitian ini untuk mengetahui hubungan asupan Vitamin E dan Selenium dengan kadar kolesterol total pada pasien penyakit jantung di Poli Jantung RSUD dr. M. Yunus Bengkulu tahun 2013. Metode yang digunakan dalam penelitian yaitu cross sectional. Analisa univariat menggunakan metode statistik, dan analisa bivariat menggunakan korelasi. Sampel berjumlah 35 orang. Hasil penelitian menunjukkan hubungan bermakna asupan vitamin $E$ dan kolesterol total $(p=0.02)$ serta asupan selenium dengan kolesterol total $(\mathrm{p}=0.037)$ pada penderita penyakit jantung.
\end{abstract}

Kata Kunci : Asupan Vitamin E, Selenium, Kadar Kolesterol Total, Penderita Penyakit Jantung

Penyakit jantung adalah penyakit yang mengganggu sistem pembuluh darah atau lebih tepatnya menyerang jantung dan uraturat darah, beberapa contoh penyakit jantung seperti penyakit jantung koroner, serangan jantung, tekanan darah tinggi, stroke, sakit di dada (angina) dan penyakit jantung rematik. Penyakit jantung koroner merupakan penyakit tertinggi yang menyerang pembuluh darah dan dapat menyebabkan serangan jantung (Asnaldi, 2008).

Serangan jantung terjadi dikarenakan pembuluh arteri tersumbat yang menghambat penyaluran oksigen dan nutrisi ke jantung. Stroke disebabkan oleh kurangnya,aliran darah yang mengalir ke otak, atau terkadang menyebabkan pendarahan di otak. Namun tidak semua penyakit jantung disebabkan oleh pembuluh darah. Penyakit jantung, stroke, dan penyakit periferal arterial merupakan penyakit yang mematikan. Di se- luruh dunia, jumlah penderita penyakit ini terus bertambah. Ketiga kategori penyakit ini tidak lepas dari gaya hidup yang kurang sehat yang banyak dilakukan seiring dengan berubahnya pola hidup. Adapun faktor-faktor resiko penyakit jantung adalah faktor usia, faktor keturunan, faktor tekanan darah tinggi, faktor kolesterol tinggi, faktor perokok, faktor diet yang jelek, kelebihan berat badan dan aktivitas fisik yang kurang, faktor masalah kesehatan lain seperti diabetes (Asnaldi, 2008).

Kolesterol adalah salah satu komponen lemak, selain trigliserida, fosfolipid, dan asam lemak bebas. Kolesterol sangat dibutuhkan oleh tubuh di samping zat gizi lain seperti karbohidrat, protein, vitamin, dan mineral. Kolesterol merupakan lemak yang sebagian besar dibentuk oleh tubuh sendiri terutama di dalam hati. Sekitar 70\% kolesterol dalam darah merupakan hasil sintesis dalam 
hati, sedangkan sisanya $30 \%$ merupakan sumbangan dari konsumsi produk hewani seperti jeroan, otak, kuning telur, daging, hasil perikanan seperti; kerang, kepiting, siput, udang, dan lain-lain. Kolesterol yang dibentuk oleh tubuh disebut kolesterol endogen dan kolesterol yang berasal dari makanan disebut kolesterol eksogen (Tirtawinata, 2006).

Kolesterol mempunyai beberapa fungsi untuk tubuh, pertama merupakan prekursor atau bahan pembentuk berbagai jenis hormon steroid antara lain hormon estrogen, progesteron dan androgen. Kolesterol juga merupakan pro vitamin D (ergosterol) yang terdapat di bawah kulit. Dengan pertolongan sinar matahari terutama sinar ultraviolet, pro-vitamin $\mathrm{D}$ diubah menjadi vitamin $\mathrm{D}$. Fungsi kolesterol berikutnya adalah sebagai bahan pembentuk asam empedu dan garam empedu (Tirtawinata, 2006).

Kebanyakan sel dalam tubuh dapat mensintesis kolesterol, sebagian besar kolesterol di dalam tubuh diperoleh dari hasil sintesis di dalam hati. Bahan bakunya diperoleh dari karbohidrat, protein atau lemak. Jumlah yang disintesis bergantung pada kebutuhan tubuh dan jumlah yang diperoleh dari makanan (Almatsier, 2002).

Kolesterol total sebenarnya merupakan susunan dari banyak zat, termasuk trigliserida, kolesterol HDL dan kolesterol LDL. Kadar kolesterol total normal $<200 \mathrm{gr} / \mathrm{dl}$, batas normal tertinggi 200-239 gr/dl, dan batas tertinggi >240 gr/dl (Iman S, 2004).

Kolesterol LDL berkemampuan menembus dinding arteri dan mulai menyumbat pembuluh darah bila telah mengami oksidasi. Bila oksidasi tidak terjadi maka LDL tidak mampu membentuk plak dan sumbatan arteri. Vitamin E adalah antioksi yang berperan mencegah terjadinya proses oksidasi dalam tubuh. Dengan demikian vitamin E dapat menghambat resiko munculnya penyakit jantung koroner (Khomsan, 2004).

Vitamin E disebut juga tokoferol. Ada tiga jenis yaitu alfa, beta, dan gamma tokoferol. Vitamin E merupakan antioksidan yang larut dalam minyak (lemak) yang bekerja secara baik di bagian tubuh yang mengandung lemak, seperti pada system kekebalan tubuh, otak, dan pembuluh-pembuluh arteri. Dimana di dalam tubuh vitamin E berperan dalam system oksidasi dan reduksi seluler yang dapat meredam dan menjinakkan radikal bebas sehingga tidak berbahaya lagi (Khomsan, 2004). Kebutuhan Vitamin E normal adalah 15 mg/hari (Widyakarya Nasional Pangan dan Gizi, 2004).

Selenium adalah trace elemen esensial dalam tubuh manusia. Mikronutrien ini merupakan bagian dari enzim yang tergantung selenium yang disebut selenoprotein. Kebutuhan selenium yang dianjurkan adalah 55 $\mathrm{mcg} /$ hari (Sieja K, 2004).

Vitamin E berfungsi untuk mengurangi kebutuhan mineral Se dengan cara mempertahankan mineral Se dalam tubuh sehingga kekurangan Se dapat ditanggulangi. Selain itu, Vitamin E dapat mencegah terjadinya rantai otot oksidasi yang reaktif dalam membrane lipid dan menghambat produksi hidroperoksida sehingga menyebabkan keracunan. Hal ini karena fungsi Se, yakni sebagian dari integral dari system enzim glutation peroxidase, merubah bentuk reaksi glutanin menjadi bentuk oksidasi glutation dan pada waktu bersamaan merusak peroksida dengan cara mengkonversi peroksida menjadi bentuk alkohol yang tidak berbahaya. Reaksi inilah yang sangat penting untuk mencegah terjadinya peroksida terhadap asam-asam lemak tak jenuh (kolesterol jahat) sehingga terbentuk sel busa yang apabila masuk ke dalam pembuluh darah ke arah jantung akan menimbulkan penyakit jantung koroner (Yohannis, 2009).

Vitamin E mudah rusak pada pemanasan seperti terjadi pada proses penggorengan dan oksidasi. Sumber vitamin E diutamakan bahan makanan dalam bentuk segar atau yang tidak terlalu mengalami pemprosesan. Pembekuan dan penggorengan dalam minyak banyak merusak sebagian besar vitamin E (Almatsier, 2003). Tujuan penelitian ini untuk mengetahui hubungan asupan Vitamin E dan Selenium dengan kadar kolesterol total pada pasien penyakit jantung di Poli Jantung RSUD dr. M. Yunus Bengkulu 


\section{BAHAN DAN CARA KERJA}

Penelitian ini dilakukan di Poli Jantung RSUD dr.M.Yunus Bengkulu. Metode yang digunakan dalam penelitian yaitu cross sectional, dengan pengambilan sampel dalam penelitian ini menggunakan teknik simple random sampling yaitu cara pengambilan sampel yang dilakukan secara acak sederhana dan proporsional (berimbang). Analisa univariat menggunakan metode statistik, dan analisa bivariat menggunakan korelasi. Sampel berjumlah 35 orang.

\section{HASIL}

\section{Analisa Univariat}

Tabel 1. Asupan Vitamin E dan Selenium dengan Kadar Kolesterol Total pada Penderita Penyakit Jantung

\begin{tabular}{cccccc}
\hline Variabel & Mean & Median & SD & Min & Maks \\
\hline $\begin{array}{c}\text { Asupan } \\
\text { Vitamin E } \\
(\mathrm{mg})\end{array}$ & 11.15 & 10.74 & 2.13 & 5.96 & 14.87 \\
$\begin{array}{c}\text { Asupan } \\
\text { Selenium } \\
(\mathrm{mcg})\end{array}$ & 44.19 & 45.21 & 5.67 & 33.80 & 58.71 \\
$\begin{array}{c}\text { Kadar } \\
\text { Kolesterol } \\
\text { Total } \\
(\mathrm{mg} / \mathrm{dl})\end{array}$ & 240.94 & 235 & 18.16 & 215 & 295 \\
\hline
\end{tabular}

Tabel 1 menunjukkan bahwa asupan vitamin $\mathrm{E}$ dan selenium penderita penyakit jantung di bawah kebutuhan normal sedangkan kadar kolesterol didapatkan nilai yang meningkat. Data menunjukkan distribusi frekuensi berbagai variabel, meliputi asupan vitamin E, selenium, dan kadar kolesterol total.

\section{Analisa Bivariat}

Hasil analisis pada tabel 2 menunjukan ada hubungan yang bermakna antara asupan vitamin $E$ dengan kadar kolesterol $(\rho=$ 0,022 ). Hubungan ini bersifat sedang dan berpola negatif $(-0,386)$, artinya semakin tinggi asupan vitamin E semakin rendah kadar kolesterol.

Hasil juga menunjukan ada hubungan bermakna antara asupan selenium dengan kadar kolesterol $(\rho=0,037)$. Uji korelasi, menunjukan hubungan yang kuat dan berpola negatif $(-0,354)$ artinya semakin tinggi asupan selenium semakin rendah kadar kolesterol total.

Tabel 2. Analisis Hubungan antara Asupan Vitamin E dan Selenium dengan Kadar Kolesterol Total pada Penderita Penyakit Jantung

\begin{tabular}{lcc}
\hline Variabel & \multicolumn{1}{c}{$\begin{array}{c}\boldsymbol{r} \text { Pearson } \\
\text { Correlation }\end{array}$} & $\boldsymbol{\rho}$ \\
\hline $\begin{array}{l}\text { Asupan Vitamin E dengan } \\
\text { Kadar Kolesterol Total }\end{array}$ & $-0,386$ & $0,022 *$ \\
$\begin{array}{l}\text { Asupan Selenium dengan } \\
\text { Kadar Kolesterol Total }\end{array}$ & $-0,354$ & $0.037 *$ \\
\hline
\end{tabular}

Ket $: * p<0.05$; sangat bermakna

\section{PEMBAHASAN}

Asupan vitamin E yang tinggi dapat menurunkan kadar kolesterol dalam darah. Dari hasil penelitian menunjukkan bahwa ratarata kadar kolesterol pada penderita penyakit jantung di RSUD dr.M. Yunus Bengkulu yai-tu 240,94 mg/dl dengan kadar kolesterol te-rendah yaitu $215 \mathrm{mg} / \mathrm{dl}$ dan kadar kolesterol tertinggi yaitu $295 \mathrm{mg} / \mathrm{dl}$. Bila dibandingkan dengan kadar kolesterol ratarata pada pasien penyakit jantung adalah tinggi. Sedangkan rata-rata asupan vitamin E pasien jantung di RSUD dr.M.Yunus Bengkulu yaitu $11.15 \mathrm{mg}$. Bila dibandingkan dengan asupan vita-min $\mathrm{E}$ yang dianjurkan rata-rata asupan vita-min $\mathrm{E}$ pasien jantung adalah kurang ( $15 \mathrm{mg} /$ hari).

Vitamin E adalah antioksidan yang berperan mencegah terjadinya proses oksidasi dalam tubuh. Dengan demikian, vitamin E dapat menghambat risiko munculnya penyakit jantung koroner (Khomsan, 2004). Selenium berfungsi sebagai komponen dari sejumlah enzim salah satunya yaitu kelompok glutathione peroksidase. Hasil penelitian menunjukkan bahwa rata-rata asupan selenium pasien jantung di RSUD dr.M.Yunus Bengkulu yaitu $44.19 \mathrm{mcg}$. Bila disbandingkan dengan asupan selenium yang dianjurkan rata-rata asupan selenium pasien jantung 
adalah rendah ( $55 \mathrm{mcg} / \mathrm{hari})$.

Hasil analisis bivariat menunjukan ada hubungan yang bermakna antara asupan vitamin E dengan kadar kolesterol $(\rho=0,022)$. Hubungan ini bersifat sedang dan berpola negatif $(-0,386)$, artinya semakin tinggi asupan vitamin E semakin rendah kadar kolesterol.

Hasil penelitian juga menunjukan ada hubungan bermakna antara asupan selenium dengan kadar kolesterol $(\rho=0,037)$. Uji korelasi, menunjukan hubungan yang kuat dan berpola negative $(-0,354)$, artinya semakin tinggi asupan selenium semakin rendah kadar kolesterol total.

Kolesterol dalam tubuh dapat diperoleh dari sintesis dalam hati dengan bahan utama lemak, karbohidrat dan protein. Banyak sedikitnya sintesis tergantung jumlah kebutuhan dan jumlah kolesterol dari makanan (Achadi, 2007).

Kolesterol LDL berkemampuan menembus dinding arteri dan mulai menyumbat pembuluh darah bila telah mengalami oksidasi. Bila oksidasi tidak terjadi maka LDL tidak mampu membentuk plak dan sumbatan arteri. Fungsi vitamin E yaitu untuk mengurangi kebuhan mineral Se dengan cara mempertahankan mineral Se dalam tubuh sehingga kekurangan Se dapat ditanggulangi. Selain itu, vitamin E dapat mencegah terjadinya rantai otot-oksidasi yang reaktif dalam membran lipid dan menghambat produksi hidroperoksida sehingga menyebabkan keracunan. Hal ini dikarenakan Se berfunsi sebagai integral dari sistem enzim glutation peroxidase, merubah bentuk reaksi glutanin menjadi bentuk oksidasi glutation dan pada waktu bersamaan merusak peroksida dengan cara mengkonversi peroksida menjadi bentuk alkohol yang tidak berbahaya. Reaksi inilah yang sangat penting untuk mencegah terjadinya peroksida terhadap asam-asam lemak tak jenuh (kolesterol jahat) sehingga terbentuk sel busa yang apabila masuk ke dalam pembuluh darah ke arah jantung akan menimbulkan penyakit jantung koroner (Yohannis, 2009).

Defisiensi vitamin E terjadi bila asupan kurang atau absorbsi terganggu. Malabsorbsi lemak juga dapat menimbulkan defisiensi vitamin E, karena pembawa vitamin ini adalah lemak. Defisiensi vitamin E dapat mempengaruhi beberapa sistem organ yang berbeda. Manifestasi kekurangan vitamin $\mathrm{E}$ sangat beragam, terkait dengan fungsinya sebagai pelindung membran sel terhadap SOR yang terbentuk selama metabolisme atau karena mempengaruhi 3 (tiga) sistem yaitu neuromuskuler, vaskuler, dan reproduksi. Kelainan yang timbul pada sistem neuromuskuler adalah ataksia, kelemahan otot, penurunan refleks-refleks, neuropati perifer, serta degenerasi saraf dan otot. Defisiensi berat yang terjadi lama dapat berakibat kebutaan, irama jantung abnormal, dan penyakit jantung (Combs GF, 1998).

Berbagai tanda defisiensi vitamin $\mathrm{E}$ ini merupakan akibat adanya disfungsi membran disebabkan degradasi oksidatif dari membran fosfolipid polyunsaturated (peroksidasi lipid) dan/atau terganggunya proses seluler penting yang lain, sehingga menyebabkan kerusakan sel dan nekrosis (Combs GF, 1998).

Vitamin E mudah rusak pada pemanasan seperti terjadi pada proses penggorengan dan oksidasi. Sumber vitamin E diutamakan bahan makanan dalam bentuk segar atau yang tidak terlalu mengalami pemprosesan. Pembekuan dan penggorengan dalam minyak banyak merusak sebagian besar vitamin E. Kekurangan vitamin E biasanya terjadi karena adanya gangguan absorpsi dan gangguan transport lipida (Almatsier, 2003).

Kadar kolesterol dalam darah manusia beragam dan mengalami peningkatan dengan bertambahnya umur. Kadar kolesterol darah dapat dipertahankan kurang dari 200 $\mathrm{mg} / \mathrm{dl}$, sedang kan dari hasil penelitian kadar kolesterol pada pasien penyakit jantung di RSUD Dr.M.Yunus Bengkulu di atas normal. Untuk mencegah kadar kolesterol darah yang tinggi, dianjurkan mengkonsumsi bahan makanan yang mengandung vitamin $E$ misalnya minyak kecambah gandum, bijibijian, sayur-sayuran, dan buah-buahan. Tidak hanya memberikan makanan yang bersumber dari daging, unggas, ikan, dan kacang-kacangan karena mengandung vita- 
min E dalam jumlah yang terbatas (Almatsier, 2003).

Selenium adalah trace elemen esensial dalam tubuh manusia. Mikronutrien ini merupakan bagian dari enzim yang tergantung selenium yang disebut selenoprotein. Absorbsi selenium tidak dipengaruhi oleh status selenium dalam tubuh. Absorbsi selenium tergantung kepada beberapa nutrisi yang lain. Vitamin A, C dan E meningkatkan absorbsi. Sedangkan merkuri menurunkan absorbsi selenium karena terbentuk endapan. Selenomethionine yang tidak langsung di metabolisme akan bergabung dengan protein tubuh dalam otot rangka, eritrosit, pankreas, hati, ginjal, lambung dan mukosa gastrointestinal (FAO/WHO, 2002). Selenium dan Vitamin E berfungsi melindungi membrane sel dari kerusakan oksidatif, sumber utama selenium adalah makanan laut, hati dan ginjal. Daging dan unggas juga merupakan sumber selenium yang baik terbatas (Almatsier, 2003).

Pada penelitian ini juga terdapat beberapa kelemahan yang mempengaruhi hasil dari penelitian yaitu dari metode yang digunakan untuk mengumpulkan data yaitu metode FFQ ketepatannya sangat tergantung pada daya ingat responden. Estimasi yang dilaku-

\section{DAFTAR RUJUKAN}

Almatsier, S., 2003, Prinsip Dasar Ilmu Gizi, PT Gramedia Pustaka Utama, Jakarta

Asnaldi, A., 2008, Jantung Koroner, di akses dari www. Eleaning Pendidikan Olahraga.15 November 2010.

Berg, JM, Tymoczko, JL., Stryer, L., 1999. Synthesizing the Molecules of Life. In: Mathews, (editor). Biochemistry: edisi ke-5.

Bustan, M.N, 2000, Epidemiologi Penyakit Tidak Menular, Rineka Cipta, Jakarta Combs GF. Vitamin E. In: Combs GF. The Vitamins, Fundamental Aspects in Nutrition and Health 2nd ed. California: Academic Press; 1998. p. 189-223.

FAO/WHO, 2002. Selenium. Human Vitamin and Mineral. FAO/WHO. Roma.

Gallagher, ML, 2004. Vitamins. In: Mahan LK, Escott-Stump S. Krause's Food, Nutrition, \& Diet Therapy. Pennsylvania: Saunders; 75-119.

Hariyatmi. 2004. Kemampuan Vitamin E sebagai kan juga mempengaruhi hasil dari perhitungan kalori asupan makanan yang dikonsumsi responden, kemungkinan adanya perbedaan untuk porsi dan Ukuran Rumah Tangga (URT) antara responden dan peneliti dalam mengestimasi makanan yang dikonsumsi responden, kemudian responden merupakan pasien yang telah terdiagnosa medis penyakit jantung dan secara langsung sudah terpapar oleh obat sehingga berkemungkinan akan mempengaruhi kadar kolesterolnya. Kelemahan lainnya yaitu terdapat juga dari desain penelitian sendiri yaitu secara cross sectional yaitu data yang diambil semuanya secara bersamaan pada waktu yang sama.

\section{KESIMPULAN}

Berdasarkan hasil penelitian dan pembahasan, disimpulkan bahwa rata-rata asupan vitamin $\mathrm{E}$ dan asupan selenium pasien jantung rendah, dan rata-rata kadar kolesterol total pada pasien penyakit jantung yaitu tinggi. Ada hubungan yang bermakna antara asupan vitamin E dan asupan selenium dengan kadar kolesterol total. Sebaiknya meningkatkan konsumsi bahan makanan yang tinggi vitamin $\mathrm{E}$ dan selenium untuk menurunkan kadar kolesterol.

Antioksidan terhadap Radikal Bebas pada Lanjut Usia. Jurnal MIPA 14 (1) : 52-60

Lanny Lingga, 2012. The Healing Power of Anti Oxidant. PT. Elex Media. Jakarta.

Komsan, A., 2003, Pangan dan Gizi untuk Kesehatan, PT Rajagrafindo Persada, Jakarta.

Moretti, Phillips M., 204. Increased Breath Marker of Oxidative Stress in Normal Pregnancy an in Preeclampsia. Am J. Obs \& Gyn 190: 11841190.

Pangemanan WT, Syamsuri AK, Saleh AZ. 1998. Hubungan antara Indeks Gestosis dengan Profil Laboraratorium pada Penderita Gestosis di RSUP Palembang. Naskah Lengkap KOGI X Padang.

Sieja K, Talerczyk M, 2004. Selenium as Element in The Treahmen of Ovarian Cancer in Women Receiving Chemotherapy. J. Gynecologic Oncology: 320-327. 